\title{
Polypeptide Profiling of Pangas Catfish (Pangasius pangasius) Serum Globulin Protein Fraction and Development of Anti-pangas Serum Globulin-HRPO Immunoconjugate for Rapid Detection of Bacterial Infection Harresh Adikesavalu', Pradipta Paul' ${ }^{1}$, Siddhartha N Joardar ${ }^{2}$ and Jawahar T Abraham ${ }^{\text {** }}$
}

${ }^{1}$ Department of Aquatic Animal Health, Faculty of Fishery Sciences, West Bengal University of Animal and Fishery Sciences, Chakgaria, Kolkata-700094, West Bengal, India

${ }^{2}$ Department of Veterinary Microbiology, Faculty of Veterinary and Animal Sciences, West Bengal University of Animal and Fishery Sciences, Belgachia, Kolkata-700037, West Bengal, India

\begin{abstract}
Bacterial diseases continue to be a major economic factor for commercial catfish farming. Correct diagnosis of diseases is, therefore, important for effective treatment measures and to prevent production losses. The present study aimed at fractionating and characterizing the serum globulin proteins of pangas catfish, Pangasius pangasius by salt fractionation and SDS-PAGE analysis. The protein profile of fractionated serum globulin proteins of $P$. pangasius revealed a total of 12 bands, viz., $136.64,120.58,95.87,79.92,72.67,63.04,45.99,43.32,38.65,34.82$, 28.46 and $19.08 \mathrm{kDa}$. Anti-pangas serum globulin (ASG) horseradish peroxidase (HRPO) immunoconjugate (ASGHRPO immunoconjugate) was prepared following sodium periodate procedure and raising immune serum against it in rabbit. The sero-reactivity of ASG-HRPO immunoconjugate was assessed by dot-ELISA and direct ELISA. In dot-ELISA, development of intense colour spot was noted only when ASG-HRPO immunoconjugate was used either at neat or 1:10 dilution. Similarly, the direct ELISA results showed low sero-reactivity with a dilution titer value $<200$ against pangas serum globulin protein fraction as antigen. Dot-ELISA was also performed to detect the presence of specific antibodies against Aeromonas hydrophila and Edwardsiella tarda in P. pangasius separately by experimental inoculation. Development of intense colour spot was observed in both cases, which in turn indicated the specificity of ASG-HRPO immunoconjugate in detecting the anti- $A$. hydrophila and anti- $E$. tarda antibodies in $P$. pangasius serum. The development of colour spot upon the addition of sensitized fish immune serum and incubation suggested that the ASG-HRPO immunoconjugate can be used for the seromonitoring of specific antibodies and serodiagnosis of diseases caused by E. tarda and A. hydrophila.
\end{abstract}

Keywords: Pangasius pangasius; Immune serum; Polypeptide profile; Immunoconjugate; Direct ELISA; Dot ELISA

\section{Introduction}

Catfish aquaculture is a fast growing sector in India and disease is a primary concern regarding economic loss in catfish aquaculture [1]. Bacterial pathogens are mainly associated with acute to chronic diseases of fish fry, fingerlings and adults resulting in severe economic loss [2]. Serodiagnosis is a routine methodology in the diagnosis and seromonitoring of infectious diseases in animals and humans. Various immunoenzyme assays have been developed to detect fish pathogens [3-6]. The most common procedure thus far developed is the enzymelinked immunosorbent assay (ELISA), which is quite common in diagnosing and studying the incidence of disease for effective control measures [7]. Klesius and Johnson [8] found the indirect ELISA to be quite useful in seroepizootiological investigations of enteric septicemia of catfish caused by Edwardsiella ictaluri. Indirect ELISA is a three tier process, firstly coating of antigen, then adding of antibody of unknown specificity and lastly addition of conjugate specific to the antibody to be detected, which is preferred to detect antibodies against a particular antigen. Shelby et al. [9] made a four tier indirect ELISA process by using mammalian conjugate due to the non-availability of anti-fish enzyme immunoconjugate to detect humoral response to Streptococcus iniae infection in Oreochromis niloticus. An alternative enzyme immunoassay that detects protein antigens bound to nitrocellulose (NC) paper was also described [6]

Both ELISA and dot-ELISA assays are similar enzyme immunoassays performed on different support substrates. The difference is that the ELISA provides a quantitative estimation of antigen and antibody which cannot be derived from dot-ELISA [10]. However, equipment involved with dot-ELISA is less expensive than that used in ELISA, which makes the dot-ELISA economically advantageous for small diagnostic laboratory. The global non-availability of conjugates to different fish species immunoglobulin (IgM) creates a major problem for screening a wide range of fish species. The present study was carried out to fractionate and characterize pangas catfish Pangasius pangasius serum globulin proteins by salt fractionation and SDS-PAGE analysis and to develop a crude horseradish peroxidase (HRPO) immunoconjugate towards pangas serum globulin proteins. The study also aimed at assessing the reactivity of the anti-pangas serum globulin (ASG) HRPO immunoconjugate (henceforth referred as ASG-HRPO immunoconjugate) and using the same in dot-ELISA to detect bacterial diseases.

\section{Materials and Methods}

\section{Collection and maintenance of fish}

The experimental pangas catfish Pangasius pangasius of weight

*Corresponding author: Jawahar Abraham T, Department of Aquatic Animal Health, Faculty of Fishery Sciences, West Bengal University of Animal and Fishery Sciences, Chakgaria, Kolkata-700094, West Bengal, India, Tel: 0442747 2905; E-mail: abrahamtj1@gmail.com

Received October 13, 2016; Accepted November 22, 2016; Published November 24, 2016

Citation: Adikesavalu H, Paul P, Joardar SN, Abraham JT (2016) Polypeptide Profiling of Pangas Catfish (Pangasius pangasius) Serum Globulin Protein Fraction and Development of Anti-pangas Serum Globulin-HRPO Immunoconjugate for Rapid Detection of Bacterial Infection . J Aquac Res Development 7: 458. doi: 10.4172/2155-9546.1000458

Copyright: ( 92016 Adikesavalu $\mathrm{H}$, et al. This is an open-access article distributed under the terms of the Creative Commons Attribution License, which permits unrestricted use, distribution, and reproduction in any medium, provided the original author and source are credited. 
Citation: Adikesavalu H, Paul P, Joardar SN, Abraham JT (2016) Polypeptide Profiling of Pangas Catfish (Pangasius pangasius) Serum Globulin Protein Fraction and Development of Anti-pangas Serum Globulin-HRPO Immunoconjugate for Rapid Detection of Bacterial Infection . J Aquac Res Development 7: 458. doi: 10.4172/2155-9546.1000458

$57.33 \pm 6.11 \mathrm{~g}$ and length $20.05 \pm 1.49 \mathrm{~cm}$ were procured from a grow-out farm in Kantipota (Lat $22^{\circ} 27^{\prime} 49^{\prime \prime} \mathrm{N}$; Long $88^{\circ} 24^{\prime} 41^{\prime \prime}$ E), South 24 Parganas district, West Bengal, India and were brought to the laboratory in oxygen filled polythene bags, disinfected with 5 ppm potassium permanganate for 15 min and stocked in 500 litre capacity fiberglass reinforced plastic (FRP) tanks containing 400 litre clean bore well water@6 fish/tank. The fish were acclimatized for two weeks and during this period they were fed with commercial pellet feed (CP 9931, Charoen Pokphand Pvt. Ltd., Andhra Pradesh, India) containing 30\% crude protein, $3 \%$ fat, $12 \%$ moisture and $8 \%$ fibre at the rate of $2 \%$ of the body weight. The wastes and faecal matter were siphoned out and $50 \%$ water exchange was done once in 4 days.

\section{Collection of pangas serum}

The fish were first anesthetized with clove oil ( $50 \mu \mathrm{l} /$ litre of water) and bled by caudal vein puncture using $2 \mathrm{ml}$ sterile non-heparinized plastic syringe. The non-heparinized blood was allowed to clot at room temperature $\left(\approx 30^{\circ} \mathrm{C}\right)$ by keeping the syringe in slanting position and kept at $4^{\circ} \mathrm{C}$ overnight. The serum was collected by centrifugation at $2500 \mathrm{rpm}$ for $15 \mathrm{~min}$ and stored at $-20^{\circ} \mathrm{C}$.

\section{Preparation of pangas serum globulin protein fraction}

The pangas serum globulin protein fraction was separated by salt fractionation method using saturated ammonium sulphate [11] with slight modification. Briefly, $5 \mathrm{ml}$ of pangas serum was precipitated by gradual addition of equal volume of $50 \%$ saturated ammonium sulphate solution ( $\mathrm{pH}$ 8.0). The suspension was allowed to stand for $30 \mathrm{~min}$ and then centrifuged at $3000 \mathrm{rpm}$ for $30 \mathrm{~min}$. The supernatant was discarded and the pellet was dissolved in $5 \mathrm{ml}$ of normal saline and precipitated again by gradual addition of equal volume of saturated ammonium sulphate solution. The suspension was again centrifuged and the cycle was repeated twice. The final precipitate was dissolved in 5 $\mathrm{ml}$ of normal saline and dialyzed against 3 changes of $0.01 \mathrm{M}$ phosphate buffer saline (PBS) to remove ammonium sulphate. Complete removal of ammonium sulphate was confirmed by adding $5 \%$ barium chloride solution. Formation of white precipitate indicated the presence of ammonium sulphate and it was dialyzed further till no precipitate was formed. After dialysis the pangas serum globulin protein fraction was filter $(\varphi 0.22 \mu)$ sterilized and stored at $-20^{\circ} \mathrm{C}$ until further use. The protein concentration of pangas serum globulin protein fraction was estimated [12].

\section{Sodium dodecyl sulphate polyacrylamide gel electrophoresis (SDS-PAGE)}

The globulin protein fraction of pangas serum was analyzed by SDS-PAGE according to Laemmli [13] using $12.5 \%$ polyacrylamide gel in a vertical mini slab gel electrophoretic apparatus. The sample was mixed with sample buffer in a proportion of 1:1 and subsequently heated at $100^{\circ} \mathrm{C}$ for $2 \mathrm{~min}$. The amount of proteins applied was $75 \mu \mathrm{g} /$ track and was allowed to run at $20 \mathrm{~mA}$ for $150 \mathrm{~min}$. Standard prestained protein molecular weight ladder, broad range was allowed to run in parallel with sample proteins to determine the relative molecular weight of the separated proteins. The bands were visualized by staining with coomassie brilliant blue R-250. The protein profile was analyzed using syngene gene tools software- file version: 4.03.01.0 of Gel Doc system (G-Box Syngene, UK).

\section{Preparation of immune serum to pangas serum globulin pro- tein fraction}

Immune serum against pangas serum globulin protein fraction was raised in rabbit as per Mishra and Sekhar [14] with minor modification. A New Zealand White (NZW) male rabbit weighing $900 \mathrm{~g}$ was injected intramuscularly with 5 doses of pangas serum globulin protein fraction, mixed with equal volume of Freund's adjuvant (Genei, Bangalore) at 10 days interval with increased subsequent doses ranging from $600 \mu \mathrm{g}$ to $1400 \mu \mathrm{g} /$ injection. First dose was given with Freund's complete adjuvant (FCA) and subsequent 4 doses with Freund's incomplete adjuvant (IFA). One week after the last dose, the rabbit was anesthetized with xylazine + ketamine ( $5 \mathrm{mg}+15 \mathrm{mg}$ administered intramuscularly) and blood was collected by cardiac puncture using $5 \mathrm{ml}$ sterile non-heparinized glass syringe. The non-heparinized blood was allowed to clot at room temperature $\left(\approx 30^{\circ} \mathrm{C}\right)$ by keeping the syringe in slanting position and kept at $4^{\circ} \mathrm{C}$ overnight. The serum was collected by centrifugation at $2500 \mathrm{rpm}$ for $15 \mathrm{~min}$ and stored at $-20^{\circ} \mathrm{C}$. Another rabbit of same breed, sex and weight was also maintained without immunization to collect normal serum.

\section{Preparation of anti-pangas serum globulin (ASG) horserad- ish peroxidase (HRPO) immunoconjugate (ASG-HRPO im- munoconjugate)}

The serum globulin protein fraction of rabbit immune serum, with specific antibodies against pangas serum globulin protein fraction, was separated by salt fractionation method using saturated ammonium sulphate [11]. The purified rabbit serum globulin protein fraction was conjugated to horseradish peroxidase (HRPO) [Genei, Bangalore] by following sodium periodate procedure [15]. Briefly, $4 \mathrm{mg}$ of HRPO was dissolved in $1 \mathrm{ml}$ of distilled water. Then $200 \mu \mathrm{l}$ of freshly prepared sodium periodate $(0.1 \mathrm{M})$ was added and stirred gently for $20 \mathrm{~min}$ at room temperature. The mixture was dialyzed overnight against sodium acetate buffer $(0.001 \mathrm{M}, \mathrm{pH} 4.4)$ at $4^{\circ} \mathrm{C}$ and $20 \mu$ of sodium carbonate buffer (0.1 M, pH 9.5) was added to the mixture to raise the $\mathrm{pH}$ to 9 . One millilitre $(1 \mathrm{ml})$ containing $8 \mathrm{mg}$ of rabbit antiserum globulin protein fraction and $100 \mu \mathrm{l}$ of freshly prepared sodium boro-hydride solution $\left(4 \mathrm{mg} / \mathrm{ml}\right.$ in distilled water) was added and incubated at $4^{\circ} \mathrm{C}$ for $2 \mathrm{~h}$. The mixture was dialyzed for $48 \mathrm{~h}$ against PBS. Finally after dialysis, equal volume of $60 \%$ glycerol in PBS was added to the newly prepared ASG-HRPO immunoconjugate and stored at $-20^{\circ} \mathrm{C}$.

\section{Qualitative and quantitative sero-reactivity assessment of ASG-HRPO immunoconjugate to pangas serum globulin protein fraction}

Dot-ELISA: Sero-reactivity of ASG-HRPO immunoconjugate to pangas serum globulin protein fraction was qualitatively assessed by dotELISA [16]. Briefly, nitro cellulose paper (NCP) strips were taken and labeled as test strips (T1 and T2) and control strip (C). The NCP strips were coated by dispensing the coating buffer (carbonate bicarbonate buffer, $\mathrm{pH}$ 9.6) containing antigen (pangas serum globulin protein fraction) in such a way that each NCP strip has 8-10 $\mu$ g of antigen. The NCP strips were incubated at $37^{\circ} \mathrm{C}$ for $2 \mathrm{~h}$ and then kept at $4^{\circ} \mathrm{C}$ overnight. The NCP strips were then dipped into blocking solution ( $3 \%$ skimmed milk and $2 \%$ gelatin in PBS) and incubated at $37^{\circ} \mathrm{C}$ for $2 \mathrm{~h}$. The strips were washed 4 times with TBST (tris base $50 \mathrm{mM}, 0.85 \%$ sodium chloride and $0.05 \%$ Tween-20) wash buffer and dried thoroughly. Then $4 \mu \mathrm{l}$ of ASG-HRPO immunoconjugate without dilution and at 1:10 dilution in PBS were dispensed on the test strips $\mathrm{T} 1$ and $\mathrm{T} 2$, respectively. The control strip received no ASG-HRPO immunoconjugate. All the $\mathrm{NCP}$ strips were incubated again at $37^{\circ} \mathrm{C}$ for $2 \mathrm{~h}$. The strips were washed 4 times with TBST wash buffer and dried thoroughly. The strips were developed by immersing in 3-3'-diaminobenzidine tetrahydrochloride (DAB system; Genei, Bangalore) substrate solution (with $\mathrm{H}_{2} \mathrm{O}_{2}$ as per 
Citation: Adikesavalu H, Paul P, Joardar SN, Abraham JT (2016) Polypeptide Profiling of Pangas Catfish (Pangasius pangasius) Serum Globulin Protein Fraction and Development of Anti-pangas Serum Globulin-HRPO Immunoconjugate for Rapid Detection of Bacterial Infection . J Aquac Res Development 7: 458. doi: 10.4172/2155-9546.1000458

manufacturer's protocol) prepared at 1:10 dilution with distilled water for $5 \mathrm{~min}$. The reaction was stopped after the colour development by rinsing in distilled water.

Direct ELISA: Direct ELISA was performed in a 96 well plate (Nune, Denmark) [14]. Briefly, the plates were coated in duplicate with coating buffer (carbonate bicarbonate buffer, $\mathrm{pH} 9.6$ ) containing antigen (pangas serum globulin fraction) in such a way that each well has 2.5 $\mu \mathrm{g}$ of antigen and kept at $4^{\circ} \mathrm{C}$ overnight. After discarding the coating buffer, blocking solution (5\% skimmed milk powder in PBS) was added and the plate was incubated at $37^{\circ} \mathrm{C}$ for $2 \mathrm{~h}$. After incubation, the plate was washed thoroughly 4 times with PBS containing 0.05\% Tween-20 (PBST). Then a 2 -fold dilution of ASG-HRPO immunoconjugate starting from 1:100 to 1:6400 in PBS was made and $100 \mu \mathrm{l}$ each of diluted ASG-HRPO immunoconjugate was added into the appropriate antigen coated wells. The plate was kept at $37^{\circ} \mathrm{C}$ for $2 \mathrm{~h}$ and washed thoroughly as mentioned above. Then $100 \mu \mathrm{l}$ of substrate solution (15 $\mu \mathrm{l}$ of $6 \% \mathrm{H}_{2} \mathrm{O}_{2}, 0.025 \mathrm{~g}$ O-phenylene diamine dihydrochloride in $25 \mathrm{ml}$ citrate buffer) was added in dark. The colour development was arrested after 20 min by adding $3 \mathrm{~N} \mathrm{HCl}$. The colour development was read at $492 \mathrm{~nm}$ using Microplate reader (Dynamica, Australia; Model: MPR96). The titer was determined at the ASG-HRPO immunoconjugate dilution which gave an optical density (OD) value corresponding to half of the maximum observed OD.

\section{Anti-Edwardsiella tarda and anti-Aeromonas hydrophila antibody detection in pangas experimentally inoculated with Edwardsiella tarda CGH9 and Aeromonas hydrophila N10P}

Preparation of bacterial cell suspension: The bacterial strains namely Edwardsiella tarda CGH9 (NCBI accession number KX159725) and Aeromonas hydrophila N10P (NCBI accession number KC914628) were from the collections of Department of Aquatic Animal Health, Faculty of Fishery Sciences, Kolkata. The glycerol stock of these strains were revived on tryptic soy agar (TSA) and maintained on TSA slants. Prior to experimentation, they were streaked separately on TSA plates and incubated at $30 \pm 2^{\circ} \mathrm{C}$ for $24 \mathrm{~h}$ to get young culture. One young discrete colony was aseptically picked from each plate and transferred to $10 \mathrm{ml}$ tryptic soy broth (TSB), marked appropriately and incubated at $30 \pm 2^{\circ} \mathrm{C}$ for $24 \mathrm{~h}$. The $10 \mathrm{ml} \mathrm{TSB}$ containing the bacterial suspension was again transferred to $300 \mathrm{ml} \mathrm{TSB}$, incubated at $30 \pm 2^{\circ} \mathrm{C}$ for $24 \mathrm{~h}$ and centrifuged at $7500 \mathrm{rpm}$ at $20^{\circ} \mathrm{C}$ for $10 \mathrm{~min}$. The cell pellet thus obtained was washed thrice with physiological saline and finally suspended in $5 \mathrm{ml}$ saline. Ten-fold serial dilutions were made and determined the counts of respective bacteria by spread plating on TSA.

Experimental inoculation: Six numbers of 300 litre capacity FRP tanks were selected, disinfected, cleaned and dried for a week. The FRP tanks, in duplicate, were labeled as test group A, test group B and control. The tanks were then filled with 200 litre of clean bore well water. Ten healthy pangas from the acclimatized stock were introduced into each tank. The tanks were covered with nylon nets for adequate protection. The $\mathrm{LD}_{50}$ values of $E$. tarda CGH9 and $A$. hydrophila N10P on pangas catfish were determined to be $3.88 \times 10^{7} \mathrm{cfu} / \mathrm{fish}$ and $4.07 \times 10^{7}$ $\mathrm{cfu} / \mathrm{fish}$, respectively (Unpublished data). The pangas of test group A and test group B were intramuscularly administered with $0.1 \mathrm{ml}$ each of diluted E. tarda CGH9 and A. hydrophila N10P cell suspensions, equivalent to a sub-lethal dose of $\approx 2.00 \times 10^{7}$ cells/fish, respectively. The control pangas received $0.1 \mathrm{ml}$ of sterile saline. The pangas were maintained in their respective tanks and observations on mortality, external signs of infection, cannibalism and behavioural changes were recorded daily. The pangas were sampled on 5, 7 and 10 day post-inoculation (dpi). On each sampling day, 2 pangas from each tank were randomly picked for the collection of serum as mentioned above.

Dot-ELISA: Anti-E. tarda and anti-A. hydrophila antibody detection in pangas experimentally inoculated respectively with $E$. tarda CGH9 and A. hydrophila N10P were qualitatively assessed by dot-ELISA [16]. Briefly, 12 nitro cellulose paper (NCP) strips were taken and labeled as group A and B with six each. Three NCP strips from group A were labeled as control (CA1, CA2 and CA3) and the remaining three were labeled as test (TA1, TA2 and TA3). Similarly, the NCP strips of group B were also labeled as control (CB1, CB2 and CB3) and test (TB1, TB2 and TB3). The NCP strips of group A were coated by dispensing coating buffer (carbonate bicarbonate buffer, $\mathrm{pH}$ 9.6) containing antigen E. tarda CGH9 outer membrane proteins (OMPs) prepared as described by Adikesavalu et al. [1] in such a way that each NCP strip has 8-10 $\mu \mathrm{g}$ of antigen. Similarly, NCP strips of group B were coated by dispensing coating buffer (carbonate bicarbonate buffer, $\mathrm{pH}$ 9.6) containing antigen A. hydrophila N10P OMPs. The NCP strips were incubated at $37^{\circ} \mathrm{C}$ for $2 \mathrm{~h}$ and then kept at $4^{\circ} \mathrm{C}$ overnight. The NCP strips were then dipped into blocking solution (3\% skimmed milk and $2 \%$ gelatin in PBS) and incubated at $37^{\circ} \mathrm{C}$ for $2 \mathrm{~h}$. The strips were washed 4 times with TBST (tris base $50 \mathrm{mM}, 0.85 \%$ sodium chloride and $0.05 \%$ Tween-20) wash buffer and dried thoroughly. The control NCP strips of both groups (A and B) were dispensed with $4 \mu \mathrm{l}$ of control pangas serum collected on 5,7 , and $10 \mathrm{dpi}$, respectively. The three test NCP strips of group A (TA1, TA2 and TA3) were dispensed with $4 \mu \mathrm{l}$ of undiluted pangas serum with specific antibodies against $E$. tarda CGH9 collected on 5, 7, and $10 \mathrm{dpi}$, respectively. Similarly, the three test NCP strips of group B (TB1, TB2 and TB3) were dispensed with $4 \mu \mathrm{l}$ of undiluted pangas serum with specific antibodies against $A$. hydrophila N10P collected on 5,7 , and $10 \mathrm{dpi}$, respectively. The NCP strips were incubated again at $37^{\circ} \mathrm{C}$ for $2 \mathrm{~h}$ and then washed thoroughly 4 times with TBST wash buffer. All the NCP strips were dispensed with $4 \mu$ of ASG-HRPO immunoconjugate at 1:10 dilution in PBS and again incubated at $37^{\circ} \mathrm{C}$ for $2 \mathrm{~h}$. The NCP strips were washed 4 times with TBST wash buffer and dried thoroughly. The strips were developed by immersing in 3-3'-diaminobenzidine tetrahydrochloride (DAB system; Genei, Bangalore) substrate solution (with $\mathrm{H}_{2} \mathrm{O}_{2}$ as per manufacturer's protocol) prepared at 1:10 dilution with distilled water for $5 \mathrm{~min}$. The reaction was stopped after the colour development by rinsing in distilled water.

\section{Results}

\section{Estimation of protein in pangas serum globulin protein fraction}

The protein concentration in pangas serum globulin protein fraction was estimated to be $5.37 \mathrm{mg} / \mathrm{ml}$.

\section{SDS PAGE}

The protein profile of serum globulin protein fraction of pangas revealed a total of 12 bands, viz., 136.64, 120.58, 95.87, 79.92, 72.67, $63.04,45.99,43.32,38.65,34.82,28.46$ and $19.08 \mathrm{kDa}$ (Figure 1).

\section{Sero-reactivity assessment of ASG-HRPO immunoconjugate to pangas serum globulin protein fraction}

Dot-ELISA: The sero-reactivity between the ASG-HRPO immunoconjugate and pangas serum globulin protein fraction was qualitatively assessed by dot-ELISA. Development of clear dense colour was observed in both dot-ELISA NCP strips T1 and T2 (Figure 2).

Direct ELISA: Direct ELISA was performed to quantitatively assess 
Citation: Adikesavalu H, Paul P, Joardar SN, Abraham JT (2016) Polypeptide Profiling of Pangas Catfish (Pangasius pangasius) Serum Globulin Protein Fraction and Development of Anti-pangas Serum Globulin-HRPO Immunoconjugate for Rapid Detection of Bacterial Infection . J Aquac Res Development 7: 458. doi: 10.4172/2155-9546.1000458

the reactivity between the ASG-HRPO immunoconjugate and pangas serum globulin protein fraction. The reactivity in terms of OD value at $492 \mathrm{~nm}$ ranged from 0.771 to 0.125 (Figure 3 ). The titer of ASG-HRPO immunoconjugate was between 1:100 and 1:200 dilutions.

\section{Anti-E. tarda and anti-A. hydrophila antibody detection in pangas experimentally inoculated with Edwardsiella tarda CGH9 and Aeromonas hydrophila N10P}

The pangas experimentally inoculated respectively with sub-lethal dose of E. tarda CGH9 and A. hydrophila N10P were observed to be under stress showing symptoms like vertical hanging, frothing on the water surface due to excess mucus production, inflammation or

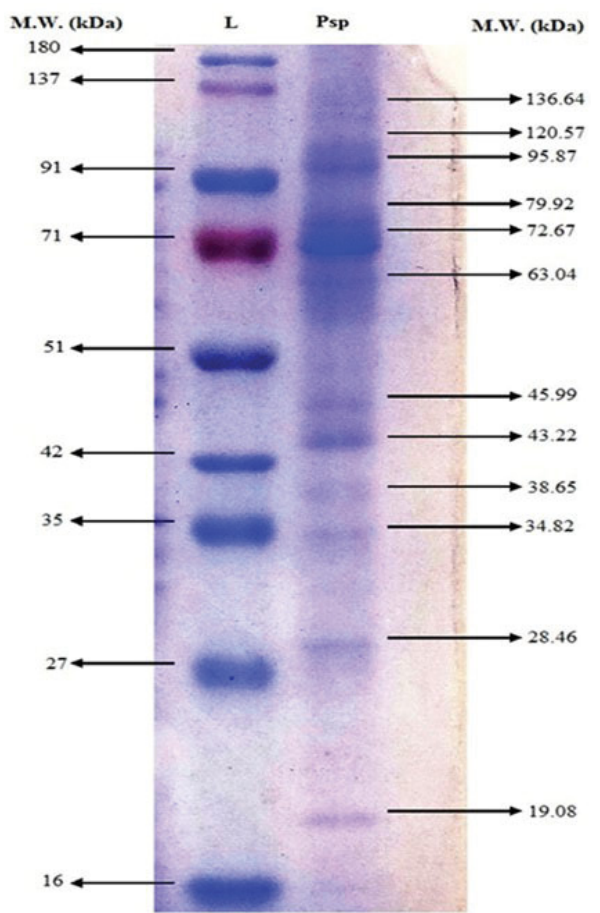

Figure 1: Protein profile of pangas serum globulin protein fraction as assessed by SDS-PAGE using coomassie blue R-250 stain; L: Pre-stained protein molecular weight ladder, broad range, Psp: Pangas serum globulin protein fraction.

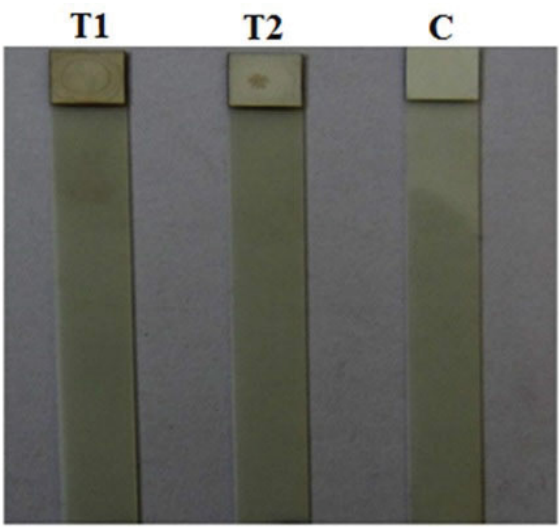

Figure 2: Dot-ELISA - Qualitative sero-reactivity assessment of ASG-HRPO immunoconjugate to pangas serum globulin protein fraction; T1: ASG-HRPO immunoconjugate without dilution, T2: ASG-HRPO immunoconjugate at 1:10 dilution, C: No enzyme immunoconjugate (Control).

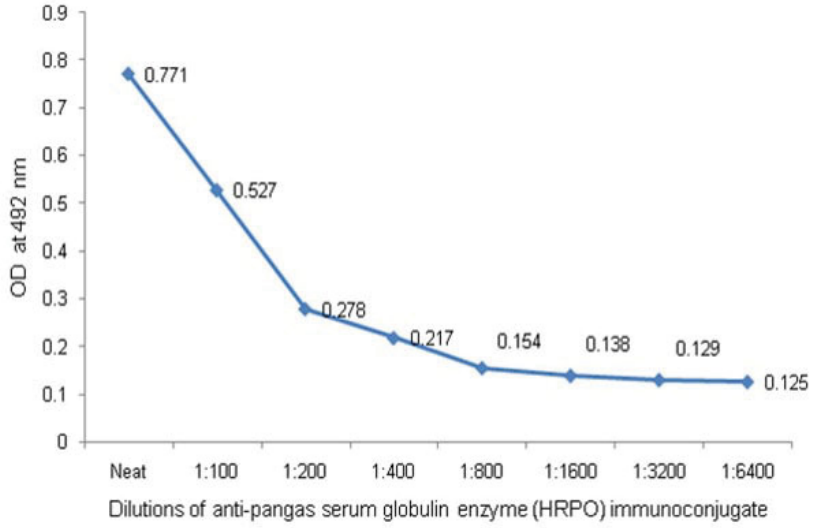

Figure 3: Quantitative sero-reactivity assessment of ASG-HRPO immunoconjugate to pangas serum globulin protein fractions by direct ELISA

\begin{tabular}{|c|c|c|c|c|}
\hline \multirow{3}{*}{$\begin{array}{c}\text { Days post } \\
\text { inoculation }\end{array}$} & \multicolumn{4}{|c|}{$\begin{array}{l}\text { Presence of antibody in the serum of experimentally } \\
\text { inoculated pangas }\end{array}$} \\
\hline & \multicolumn{2}{|c|}{ Anti- E. tarda antibody } & \multicolumn{2}{|c|}{ Anti- A. hydrophila antibody } \\
\hline & Control & Test & Control & Test \\
\hline 5 & - & - & - & - \\
\hline 7 & - & - & - & - \\
\hline 10 & - & + & - & + \\
\hline
\end{tabular}

Table 1: Presence of antibody in pangas serum experimentally inoculated with Edwardsiella tarda CGH9 and Aeromonas hydrophila N10P.

ulceration at the site of injection, petechial hemorrhages and fin/tail haemorrhages.

Dot-ELISA was performed to qualitatively detect the presence of anti-E. tarda antibody and anti-A. hydrophila antibody in sensitized pangas serum from groups $\mathrm{A}$ and $\mathrm{B}$, after experimentally inoculating with E. tarda CGH9 and A. hydrophila N10P, respectively. No colour development was observed immediately after the addition of substrate in control NCP strips of groups A and B when control pangas serum collected on 5, 7 and 10 dpi were used (Table 1). The test NCP strips TA1 and TA2 of group A showed no colour development, when $E$. tarda CGH9 sensitized pangas serum (without dilution) collected respectively on 5 and $7 \mathrm{dpi}$ were used (Table 1). A clear dot-like colour development was observed immediately after the addition of substrate in test NCP strip TA3 of group A, when E. tarda CGH9 sensitized pangas serum (without dilution) collected on $10 \mathrm{dpi}$ was used (Table 1 and Figure 4). Similarly, the test NCP strips TB1 and TB2 of group B showed no colour development, when A. hydrophila N10P sensitized pangas serum (without dilution) collected respectively on 5 and $7 \mathrm{dpi}$ were used (Table 1). A clear dot-like colour development was observed immediately after the addition of substrate in test NCP strip TB3 of group B, when A. hydrophila N10P sensitized pangas serum (without dilution) collected on $10 \mathrm{dpi}$ was used (Table 1 and Figure 5).

\section{Discussion}

The present study attempted to profile the P.pangasius serum globulin protein fraction and to develop an anti-fish enzyme immunoconjugate for rapid detection of bacterial diseases by dot-ELISA. As elucidated electrophoretically, the $P$. pangasius serum globulin protein fraction was separated into 12 bands with molecular weight 136.64, 120.58, 95.87, $79.92,72.67,63.04,45.99,43.32,38.65,34.82,28.46$ and $19.08 \mathrm{kDa}$. In a similar study Gaikwad et al. [17] electrophoretically analysed the serum protein profile of air breathing fish Channa gachu, which revealed a total of 11 protein bands. Five protein bands, viz., 72.67, 63.04, 45.99, 43.22 


\section{TA3}

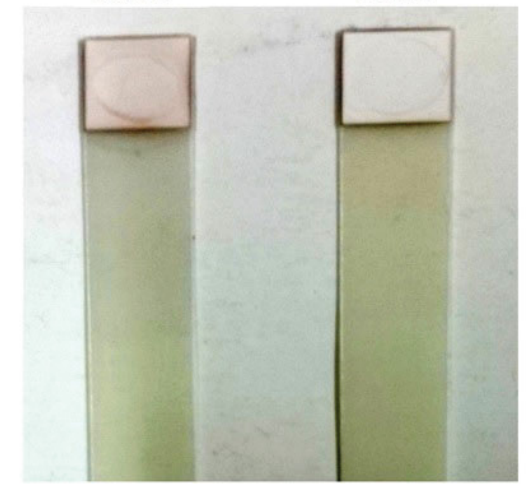

Figure 4: Dot-ELISA - Detection of rabbit anti-E. tarda antibody in sensitized pangas serum collected on 10 dpi by using ASG-HRPO immunoconjugate at 1:10 dilution; CA3: Test performed with control pangas serum collected on 10 dpi without dilution, TA3: Test performed with sensitized pangas serum with specific antibodies against $E$. tarda CGH9 collected on $10 \mathrm{dpi}$ as primary antibody without dilution.

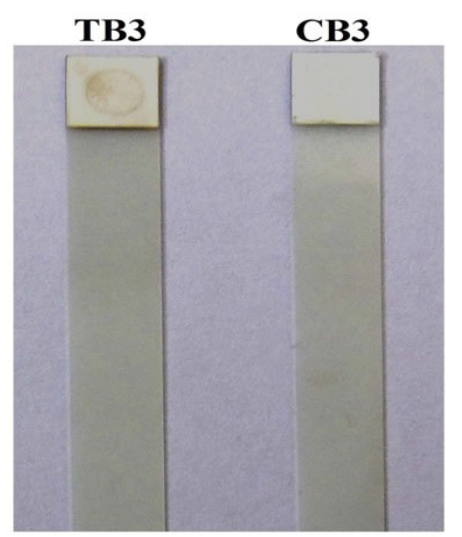

Figure 5: Dot-ELISA- Detection of rabbit anti-A. hydrophila antibody in sensitized pangas serum collected on 10 dpi by using ASG-HRPO immunoconjugate at 1:10 dilution; CB3: Test performed with control pangas serum collected on 10 dpi without dilution, TB3: Test performed with sensitized pangas serum with specific antibodies against $A$. hydrophila N10P collected on 10 dpi as primary antibody without any dilution.

and $34.82 \mathrm{kDa}$ of the present study were found to be in close match with the serum protein bands, viz., 71.61, 63.13, 45.29, 42.24 and $35.62 \mathrm{kDa}$ of air breathing fish C. gachu [17]. An electrophoretic taxonomic study on the serum proteins of Clarias gariepinus [18] revealed a total of 15 protein bands, which was also in close match with that of the present study. The differences observed in the number of protein bands could be attributed to the genetic variation that exists between species.

Earlier works on fish immunoglobulin indicated that teleost produce a single tetrameric immunoglobulin (IgM) like antibody, analogous to mammalian IgM [19]. In SDS-PAGE, purified fish immunoglobulin dissociate into two bands which could be identified as heavy $(\mathrm{H})$ and light (L) chains of immunoglobulin. An earlier report suggested that the molecular weight of $\mathrm{H}$ and $\mathrm{L}$ chains of fish IgM varied from 60-77 $\mathrm{kDa}$ and 23-26 kDa, respectively for bony fishes [20]. While, the IgM of Asian seabass, Lates calcarifer possessed $\mathrm{H}$ and $\mathrm{L}$ chains with higher molecular weight of $83 \mathrm{kDa}$ and $27 \mathrm{kDa}$, respectively [21]. Similarly, the serum IgM of Clarias batrachus was characterized, which identified two $\mathrm{H}$ chain subunits with molecular weights of approximately $66.28 \pm 0.20$ $\mathrm{kDa}$ and $59.32 \pm 0.40 \mathrm{kDa}$, and two $\mathrm{L}$ chain subunits of approximately
$27.63 \pm 0.15 \mathrm{kDa}$ and $26.40 \pm 0.20 \mathrm{kDa}$ [22]. In the present study, two protein bands namely 79.92 and $72.67 \mathrm{kDa}$ in the molecular weight range of $\mathrm{H}$ chain and one protein band $(28.46 \mathrm{kDa})$ in the molecular weight range of $\mathrm{L}$ chain of fish IgM were noted. Likewise, Sudhagar et al. [11] identified two protein bands of size 70.1 and $26 \mathrm{kDa}$ as $\mathrm{H}$ and L chains, respectively in the purified serum IgM of Pangasianodon hypophthalmus. Presumably, the protein band with a molecular weight of $72.67 \mathrm{kDa}$ of the present study could be considered as $\mathrm{H}$ chain of pangas serum IgM as both P. pangasius and P. hypophthalmus belong to the same Family/Class. The other protein bands observed in the present study could be $\beta$-globulins, haptoglobins, transferrins and albumin like protein. Apart from immunoglobulin (IgM), Ahmad et al. [23] also reported the distribution of major serum proteins like $\beta$-globulins, haptoglobins, transferrins and albumin like protein in air-breathing teleost, Channa punctata. The variations in the molecular weight of IgM molecules in different fish species might have arisen due to the differences in their genome.

Dot-ELISA was performed to qualitatively assess the reactivity; while direct ELISA was performed to quantitatively assess the reactivity between the ASG-HRPO immunoconjugate and pangas serum globulin protein fraction. A clear dense colour development was observed in both dot-ELISA NCP strips T1 and T2 previously coated with pangas globulin fraction. This indicated that the ASG-HRPO immunoconjugate was able to capture pangas globulin fraction, but only when used at high concentration, i.e., without dilution and/or at 1:10 dilution. The poor or low reactivity of ASG-HRPO immunoconjugate could be attributed to the use of crude pangas serum globulin protein fraction to raise antiserum in rabbit. Also, while preparing the ASGHRPO immunoconjugate, the serum globulin fraction from rabbit antiserum was used directly without purifying the immunoglobulin $G$ (IgG). Nevertheless, the results showed a positive relationship between the direct ELISA OD value and various concentration of a two-fold diluted ASG-HRPO immunoconjugate as the ELISA OD value reduced with ASG-HRPO immunoconjugate concentration. The titer of the ASG-HRPO immunoconjugate was between 1:100 and 1:200 dilutions as the $\mathrm{OD}$ value corresponding to half of the maximum observed OD was greater than the OD observed at 1:100 dilution and lesser than that observed at 1:200 dilution. This suggested that a single dilution at 1:100 of ASG-HRPO immunoconjugate was found to be adequate for determining pangas serum globulin protein fraction. In ELISA, the use of antibody at a single dilution, rather than the need for multiple dilutions, was considered as an important advantage.

In this study dot-ELISA assay was adapted for the detection of anti-E. tarda and anti-A. hydrophila antibody, which is nothing but globulin $(\gamma)$ proteins found in pangas experimentally inoculated with E. tarda CGH9 and A. hydrophila N10P, respectively. By using the ASGHRPO immunoconjugate, the dot-ELISA reliably detected anti-E. tarda and anti-A. hydrophila antibodies in pangas serum sensitized with respective bacterium on $10 \mathrm{dpi}$, but not in sensitized pangas serum collected on 5 and 7 dpi. Klesius et al. [4] reported that the ELISA reliably detected the anti-E. ictaluri antibody in fish sera only after eight days of experimental infection with E. ictaluri and our observations provide supportive evidence to their results. Although the reactivity of ASG-HRPO immunoconjugate was less towards pangas serum globulin protein fraction, it has the ability to detect anti-E. tarda and/ or anti-A. hydrophila antibodies in sensitized pangas sera in dot-ELISA. Plausibly, these results suggest that the ASG-HRPO immunoconjugate can be used in dot-ELISA assay for qualitative serodiagnosis of various bacterial fish pathogens by just changing the primary antiserum. In addition, quantitative assessment of antibody in the sera of infected 
Citation: Adikesavalu H, Paul P, Joardar SN, Abraham JT (2016) Polypeptide Profiling of Pangas Catfish (Pangasius pangasius) Serum Globulin Protein Fraction and Development of Anti-pangas Serum Globulin-HRPO Immunoconjugate for Rapid Detection of Bacterial Infection . J Aquac Res Development 7: 458. doi: 10.4172/2155-9546.1000458

and/or immunized pangas over a period of time could be detected by adapting indirect ELISA.

\section{Conclusion}

In conclusion, this is the first crude attempt in developing enzyme (HRPO) immunoconjugate towards $P$. pangasius serum globulin protein fraction. Since the diagnosis of a particular infection based on the detection of its causative agent always proves to be the best method, the ASG-HRPO immunoconjugate can, therefore, be utilized for the serodiagnosis of bacterial fish pathogens in P. pangasius. The rapid fish diagnosis of a particular bacterial infection in fish by ELISA could make treatment more cost-effective. Further work is, however, necessary to improve the specificity of anti-pangas serum globulin enzyme (ASGHRPO) immunoconjugate and also to assess the cross-reactivity towards serum globulin proteins of other catfish species.

\section{Acknowledgements}

The research work was supported by the Indian Council of Agricultural Research, Government of India, New Delhi under the Niche Area of Excellence programme. The authors thank the Vice-Chancellor, West Bengal University of Animal and Fishery Sciences, Kolkata for providing necessary infrastructure facility to carry out the work.

\section{Conflict of interest}

The authors declare that there is no conflict of interest.

\section{References}

1. Adikesavalu H, Paul P, Priyadarsani L, Banerjee S, Joardar SN, et al. (2016) Edwardsiella tarda induces dynamic changes in immune effector activities and endocrine network of Pangasius pangasius (Hamilton, 1822). Aquaculture 462: 24-29.

2. Austin B, Austin DA (2007) Bacterial fish pathogens: Diseases of farmed and wild fish. (3rdedn), Springer-Praxis, Godalming, UK.

3. Cipriano RC, Pyle JB, Starliper CE, Pyle SW (1985) Detection of Vibrio anguillarum antigen by the dot blot assay. Journal of Wildlife Diseases 21 : 211-218

4. Klesius P, Johnson K, Durborow R, Vinitnantharat S (1991) Development and evaluation of an enzyme-linked immunosorbent assay for catfish serum antibody to Edwardsiella ictaluri. Journal of Aquatic Animal Health. 3: 94-99.

5. Denzin N, Staak C (2000) Fish immunoglobulin - A serodiagnosticians perspective. Bulletin-European Association of Fish Pathologist 20: 60-64.

6. Hawkes R, Niday E, Gordon J (1982)A dot immunobinding assay for monoclona and other antibodies. Analytical Biochemistry 119: 142-147.

7. Karunasagar I, Karunasagar S (1999) Diagnosis, treatment and prevention of microbial diseases of fish and shellfish. Current Science 76: 387-399.
8. Klesius P, Johnson K (1991) Development of an enzyme-linked immunosorbent assay for catfish serum antibody to Edwardsiella ictaluri. Journal of Aquatic Animal Health 3: 94-99.

9. Shelby RA, Shoemaker CA, Evans JJ, Klesius PH (2001) Development of an indirect ELISA to detect humoral response to Streptococcus inniae infection of Nile tilapia, Oreochromis niloticus. Journal of Applied Aquaculture 11: 35-44.

10. Bullock GR (1991) ELISA techniques: New developments and practical applications in a broad field. Techniques in Diagnostic Pathology ( $2^{\text {nd }}$ issue) Academic Press, The University of Michigan, USA

11. Sudhagar SA, Prasad KP, Makesh M, Rathi G (2013) Characterization and production of polyclonal antisera against pangasius (Pangasianodon hypophthalmus) serum immunoglobulin IgM derived from DEAE cellulose based ion exchange chromatography. Aquaculture Research 46: 1417-1425

12. Lowry OH, Rosenberough NJ, Farr AL, Randal RJ (1951) Protein measurement with folin phenol reagent. Journal Biological Chemistry 193: 265-275.

13. Laemmli UK (1970) Cleavage of structural proteins during assembly of the head of bacteriophages T4. Nature 227: 680-685.

14. Mishra SS, Sekhar MS (1997) ELISA and dot immunoassay for detection of Vibrio spp. in tiger shrimp Penaeus monodon. Indian Journal of Fisheries 44 369-376

15. Wilson MB (1978) Recent development in the periodate method of conjugating horseradish peroxidase (HRPO) to antibodies. Immunofluorescence and related staining techniques. Elsevier/North Holand Biomedical Press, The Netherlands.

16. Maji S, Mali P, Joardar SN (2006) Immunoreactive antigens of the outer membrane protein of Aeromonas hydrophila isolated from goldfish, Carassius auratus (Linn.). Fish and Shellfish Immunology 20: 462-473.

17. Gaikwad MV, Davane PM, More VR, Shaikh FK, Jaiwal BV, et al. (2012) Protein profile in serum of air breathing fish, Channa gachu (Ham). International Journa of Pharma and Biosciences 1: 628-633.

18. Majolagbe FA, Awodiran MO, Awopetu JI (2012) Electrophoretic studies of Clarias gariepinus (Burchell 1822) and Heterobrancbus bidorsalis (Geoffroy Saint-Hilaire 1809) and their hybrids. Ife Journal of Science 14: 167-176.

19. Pilstrom L, Bengten $E$ (1996) Immunoglobulin in fish - genes, expression and structure. Fish and Shellfish Immunology 6: 243-262.

20. Muiswinkel VWB, Woo PTK (1995) The piscine immune system: innate and acquired immunity. Fish diseases and disorders. CAB International, Wallingford, UK

21. Choudhury M, PaniPrasad K (2011) Isolation and characterization of immunoglobulin $\mathrm{M}$ of Asian seabass, Lates calcarifer and its level in serum. Open Life Sciences 6: 180-187.

22. Swain T, Mohanty J, Sahu AK (2004) One step purification and partia characterization of serum immunoglobulin from Asiatic catfish (Clarias batrachus L.). Fish and Shellfish Immunology 17: 397-401.

23. Ahmad R, Khan KA, Hasnain AU, Qayyum S (2007) Distribution of majo serum proteins in an air-breathing teleost, Channa punctata $\mathrm{BI}$ (Channidae: Channiformes). Biomedical Research 18: 123-128. 